\title{
Depositional architecture of the late Ordovician drowned carbonate platform margin and its responses to sea-level fluctuation in the northern slope of the Tazhong region, Tarim Basin
}

\author{
Yang Xiaofa ${ }^{1,2}$, Lin Changsong ${ }^{*}$, Yang Haijun ${ }^{3}$, Han Jianfa ${ }^{3}$, Liu Jingyan ${ }^{1}$, \\ Zhang Yanmei ${ }^{4}$, Peng Li $^{1}$, Jing Bing ${ }^{3}$, Tong Jianyu ${ }^{1}$, Wang Haiping ${ }^{1}$ and Li \\ Huanpu ${ }^{1}$ \\ ${ }^{1}$ School of Energy Resources, China University of Geosciences, Beijing 100083, China \\ ${ }^{2}$ State Key Laboratory of Lithospheric Evolution, Institute of Geology and Geophysics, Chinese Academy of Sciences, \\ Beijing 100029, China \\ ${ }^{3}$ Tarim Oil \& Gas Exploration and Development Research Institute, Korla, Xinjiang 841000, China \\ ${ }^{4}$ Department of Computer Sciences, China University of Geosciences, Beijing 100083, China
}

(C) China University of Petroleum (Beijing) and Springer-Verlag Berlin Heidelberg 2010

\begin{abstract}
The Tazhong Uplift of the late Ordovician is a drowned rimmed carbonate platform. The carbonate rock of the late Ordovician Lianglitage Formation in the northern slope of the Tazhong region is one of the significant petroliferous intervals. Based on petrofacies, depositional cycles, natural gammaray spectrometry and carbon/oxygen isotope data from the Lianglitage Formation, one 2nd-order, three 3rd-order and several 4th-order sequences have been recognized, and the late Ordovician relative sealevel fluctuation curve has been established. The sequences $\mathrm{O}_{3} \mathrm{l}-1$ and $\mathrm{O}_{3} 1-2$ on the platform are composed of highstand and transgressive systems tracts, but lack the lowstand systems tract. The sequence $\mathrm{O}_{3} 1-3$ is a drowning sequence. The sequence $\mathrm{O}_{3} \mathrm{l}-1$ overlapped the eroded slope and pinched out to the northwest and landward. The highstand systems tract in the sequence $\mathrm{O}_{3} \mathrm{l}-2$ consists of low-angle sigmoid and high-angle shingled progradation configuration. Major sedimentary facies of the Lianglitage Formation include reef and shoal in the platform margin and lagoon, which can be subdivided into coral-sponge-stromatoporoid reef complex, sand shoal, lime mud mound, and intershoal sea. Reefs, sand shoals and their complex are potential reservoir facies. The reefs and sand shoals in the sequence $\mathrm{O}_{3} \mathrm{l}-1$ developed in the upper of its highstand systems tract. In the sequence $\mathrm{O}_{3} \mathrm{l}-2$, the highstand systems tract with an internal prograding configuration is a response to the lateral shifting of the complex of reef and sand shoal. The transgressive systems tract, in particular the sand shoals, developed widely on the slope of the platform margin and interior. The reefs in the sequence $\mathrm{O}_{3} \mathrm{l}-3$ migrated towards high positions and formed retrograding reefs in the western platform and low relief in the platform interior. Basinward lateral migration of the reefs and pure carbonate rock both characterize highstand systems tract and show that the rise of the relative sea-level was very slow. Shingled prograding stacking pattern of the 4th-order sequences and reefs grow horizontally, which represents the late stage of highstand systems tract and implies relative sealevel stillstand. Reefs migrating towards high land and impure carbonate rock both indicate transgressive systems tract and suggest that the relative sea-level rose fast. Erosional truncation and epidiagenetic karstification represent a falling relative sea-level. The relative sea-level fluctuation and antecedent palaeotopography control the development and distribution of reef complexes and unconformity karst zones. Currently, the composite zone of epidiagenetic karstic intervals and high-energy complexes of reefs and sand shoals with prograding configuration is an important oil and gas reservoir in the northern slope of the Tazhong carbonate platform.
\end{abstract}

Key words: Tarim Basin, late Ordovician, carbonate platform, depositional architecture, sea-level fluctuation

*Corresponding author. email: lincs@cugb.edu.cn Received March 16, 2009

\section{Introduction}

The Tarim Basin is a large-scale superimposed basin developed on the pre-Sinian continental crust basement 
(Jia, 1997; He et al, 2007). The Tazhong region, located in the central Tarim Basin, has an area of $27,000 \mathrm{~km}^{2}$ (Fig. 1). It is bordered by the Manjiaer Depression on the north, Tangguzibasi Depression on the south, Bachu Uplift on the west and Tadong Uplift on the east (Jia, 1997). The Ordovician carbonate formation is an important target for exploration in the Tazhong region, and a series of Ordovician oil and gas fields have been discovered so far (He et al, 2007; Zhao et al, 2009). The carbonate rock of the late Ordovician Lianglitage Formation in the northern slope of the Tazhong region is one of the significant petroliferous intervals in the Tarim Oilfield (Lü et al, 2007; Li et al, 2009; Zhou et al, 2009).

The Tazhong Uplift of the late Ordovician is a rimmed carbonate platform (Gu et al, 2005; Xu et al, 2005; Feng et al, 2007; Chen et al, 2009). The growth of the platform was controlled by the interaction of tectonic subsidence, sea-level change, sedimentation, antecedent terrain, and climate (Sarg, 1998; Eberli et al, 2004). Tectonic and eustatic processes cause relative changes in sea-level, which control the space available for sediments to accumulate on the platform tops (accommodation space) (Schlager, 1992). The structural slope-break zone in the fault subsidence basin controls the development of depositional sequences. The large-scale architecture of carbonate platforms and shelves is controlled by the interplay between the relative sea-level change and the growth rate of carbonate rocks (Eberli et al, 2004). Repeated exposure and the associated diagenetic changes of carbonate platforms have a major impact on porosity evolution and reservoir quality (Vahrenkamp et al, 2004; Lü et al, 2008; Zhang and Liu, 2009).

The discussion in the study area (Fig. 1) is focused on how to recognize and correlate the 3rd-order and 4th-order sequences in the late Ordovician Lianglitage Formation. Some authors (Yu et al, 2001; Zhao et al, 2004; 2010; Chen et al, 2006; Chen et al, 2007; Gao et al, 2007; Kang et al, 2010) drew different conclusions based on different data. The establishment of a stratigraphic sequence framework of the Lianglitage Formation relies on sedimentary genetic analysis and the construction of comparable criteria. The types of the carbonate reservoirs in Tazhong are diversified and complicated. The temporal and spatial distribution of the carbonate reservoirs is still not well understood. One of the methods is to study the sedimentary facies distribution, especially the distribution of reefs and sand shoals.

Currently, good-quality 3-D seismic data were acquired in the study area. As well no less than 33 exploration wells have been drilled in the Lianglitage Formation, some of which have been extensively cored with high recovery. Based on the above data, we use sequence stratigraphy, geochemistry and seismic sedimentology (Zeng and Ambrose, 2001) to study sequence stratigraphy, sedimentary facies distribution, and sea-level fluctuations of the late Ordovician in the Tazhong region, discuss how the sea-level change controls carbonate sedimentary facies and their associations, and reveal the conditions of the formation of reservoirs from the background of the evolution of the ancient ocean.

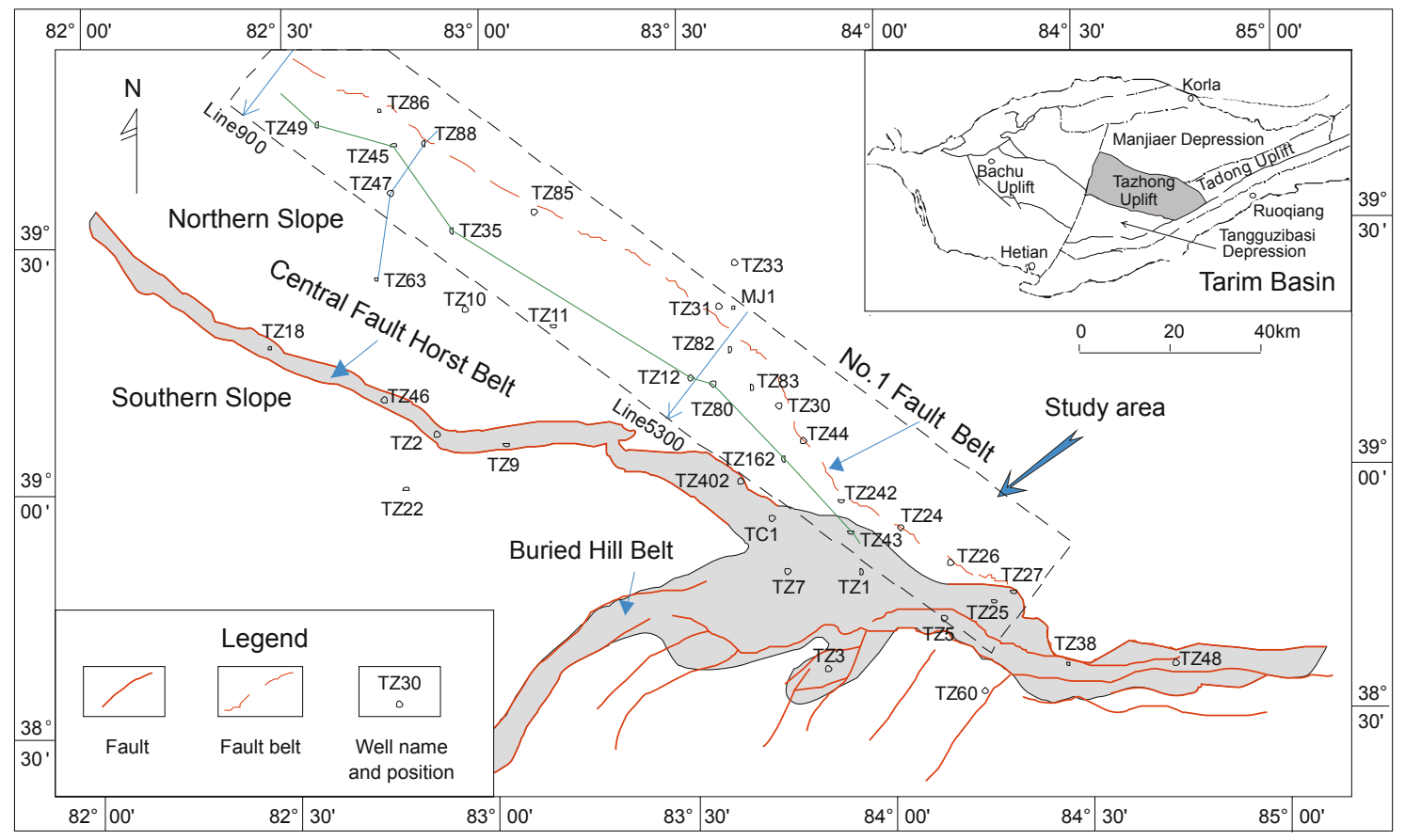

Fig. 1 Map of the study area and tectonic framework

\section{Geological setting}

The structure of the Tazhong region is complex, containing a large, northwest-trending reverse fault (No. 1 Fault Belt), which cuts both the Ordovician and Silurian (Jia, 1997). A nearly east-west Central Fault Horst Belt exists in the high position of the Tazhong Uplift, dividing the Tazhong Uplift into the northern slope and the southern slope (Zhang et al, 2008). Apart from these two main structures, there is a series of relatively minor faults, suggesting that the formation in this area underwent several tectonic events. Most of the faults, including the No. 1 Fault Belt, are extensional/ 
transtensional in the Sinian-Early Cambrian, and become compressional/transpressional in the middle-late Caledonian (Jia, 1997; Lin et al, 2009), characterized by subsidence, uplift and erosion. Faults and unconformity surfaces formed during the two periods of tectonism provide the main pathways for hydrocarbon migration (Zhang et al, 2008).

The Ordovician system is mainly composed of shallowwater carbonate rocks in the Tazhong Uplift. A fourfold Ordovician lithostratigraphic subdivision is recognized in the Tazhong Uplift. The Early Ordovician Penglaiba Formation $\left(\mathrm{O}_{1} \mathrm{p}\right)$ is $500-1,500 \mathrm{~m}$ thick and consists of limestone interbedded with dolomite. The Early-Mid Ordovician Yingshan Formation $\left(\mathrm{O}_{1-2} \mathrm{y}\right)$ is $200-700 \mathrm{~m}$ thick and dominated by dolomitic limestone. The late Ordovician Lianglitage Formation $\left(\mathrm{O}_{3} 1\right)$ unconformably overlies the Yingshan Formation. This formation is $120-880 \mathrm{~m}$ thick and consists of pure limestone. The overlying Sangtamu Formation $\left(\mathrm{O}_{3} \mathrm{~s}\right)$ is $100-1,050 \mathrm{~m}$ thick and consists of terrigenous fine clastics. The mid-late Ordovician Yijianfang and Tumuxiuke formations are absent in the Tazhong region.

According to the lithological and paleobiological data, the Lianglitage Formation can be subdivided into three members from bottom to top, namely argilliferous limestone, grainstone and argillaceous striped limestone (Yang et al, 2000). The lower member is $50-550 \mathrm{~m}$ thick and consists of dark micrite and grainstone, interbedded with irregular siliceous mudstone. The middle member is $50-150 \mathrm{~m}$ thick and dominated by grainstone, reef limestone interbedded with micrite. The upper member is 20-100 m thick and widely distributed in the study area. This member is composed of micrite interbedded with striped mudstone, and some grainstone and reef.

\section{Sequence stratigraphic framework of the Upper Ordovician}

The 2nd-order sequences or composite sequences are bounded by basin-scale unconformities and the 3rd-order sequences are bounded by regional-scale unconformities (Vail et al, 1991). Large scale sequences can be recognized by 3-D seismic profiles, well-logs and cores. The 4th-order sequences are defined on the basis of stacking patterns of smaller-scale sequences and are bounded by major flooding surfaces (Lin et al, 2002). Based on seismic, well log and core data (Figs. 2 to 8 ), the Lianglitage Formation in the study area can be divided into one 2nd-order sequence and further subdivided into three 3rd-order sequences.

\subsection{Characteristics of the 2 nd-order sequence boundary}

The Lianglitage Formation is bounded at the top and bottom by 2 nd-order sequence boundaries $\mathrm{T}_{\mathrm{g}} 5^{1}$ and $\mathrm{T}_{\mathrm{g}} 5^{2}$ respectively (Fig. 2). $\mathrm{T}_{\mathrm{g}} 5^{1}$ is a drowning unconformity, and $\mathrm{T}_{\mathrm{g}} 5^{2}$ is a subaerial exposed unconformity.

$\mathrm{T}_{\mathrm{g}} 5^{2}$ is an angular unconformity in the eastern platform in the study area, and transforms to a parallel unconformity westward. In seismic profiles, the parallel unconformity shows discontinuous seismic reflection events following bedding planes (Fig. 2), and concave reflection zones that are interpreted as dolines can be found locally. Core inspection and thin-section petrography of many wells show that
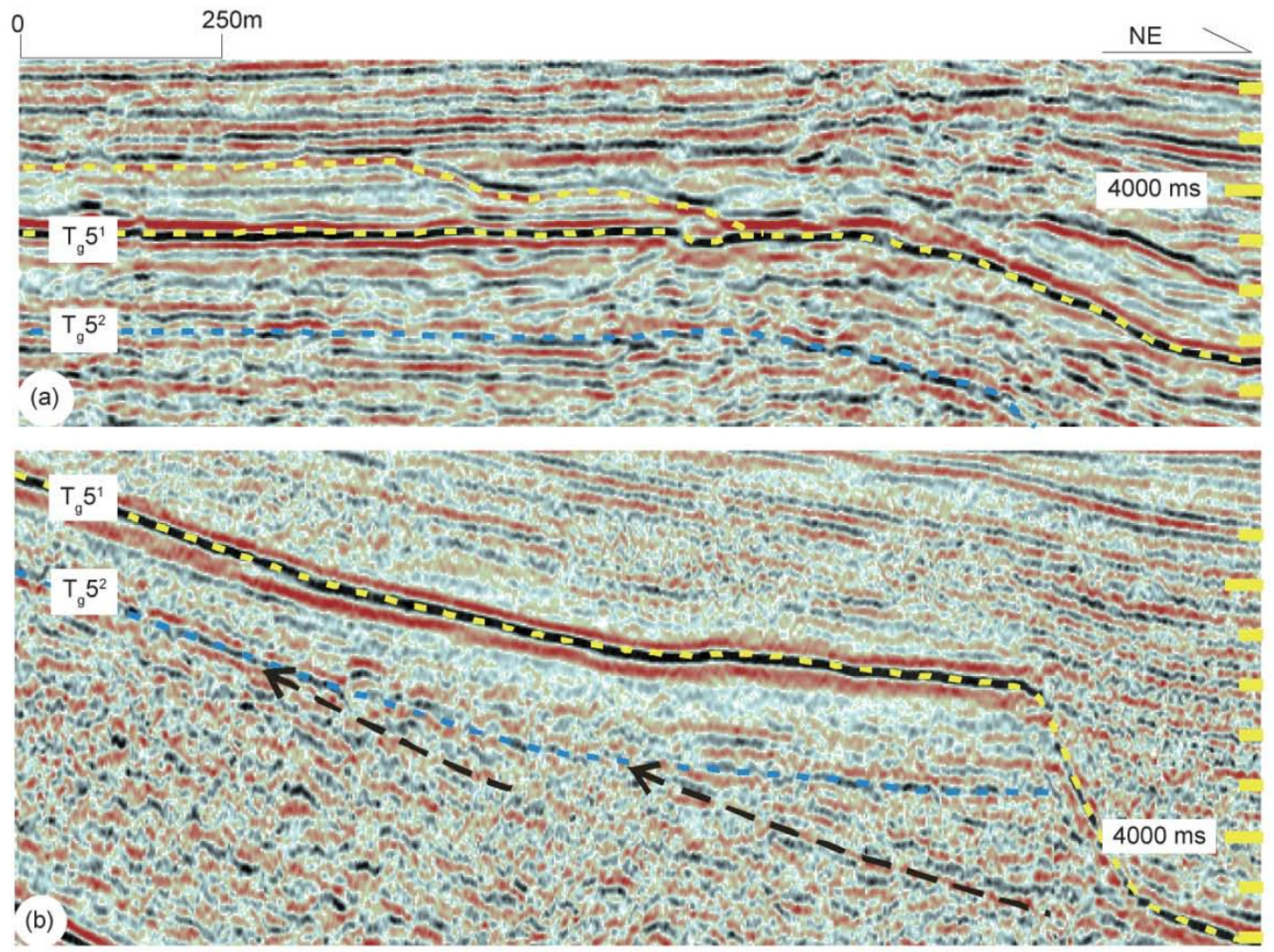

Fig. 2 Seismic reflection characteristics of the Lianglitage Formation in the study area (a is Line 900 and b is Line 5300 ). See Fig. 1 for the locations of the seismic profiles 
secondary corrosion holes, breccia or vadose silt appear near $\mathrm{T}_{\mathrm{g}} 5^{2}$.

It is easy to recognize $\mathrm{T}_{\mathrm{g}} 5^{1}$ from seismic profiles. Acoustic impedance between the Lianglitage Formation and Sangtamu Formation is much different, because of the abrupt changes of lithology from carbonate rock to siliciclastic mudstone (Figs. 3,4 and 5). In addition, almost all the log curves show abrupt changes near the 2 nd-order sequence boundary $\mathrm{T}_{\mathrm{g}} 5^{1}$ and $\mathrm{T}_{\mathrm{g}} 5^{2}$.

The thickness of the 2 nd-order sequence is maximum at the platform margin and becomes smaller rapidly toward

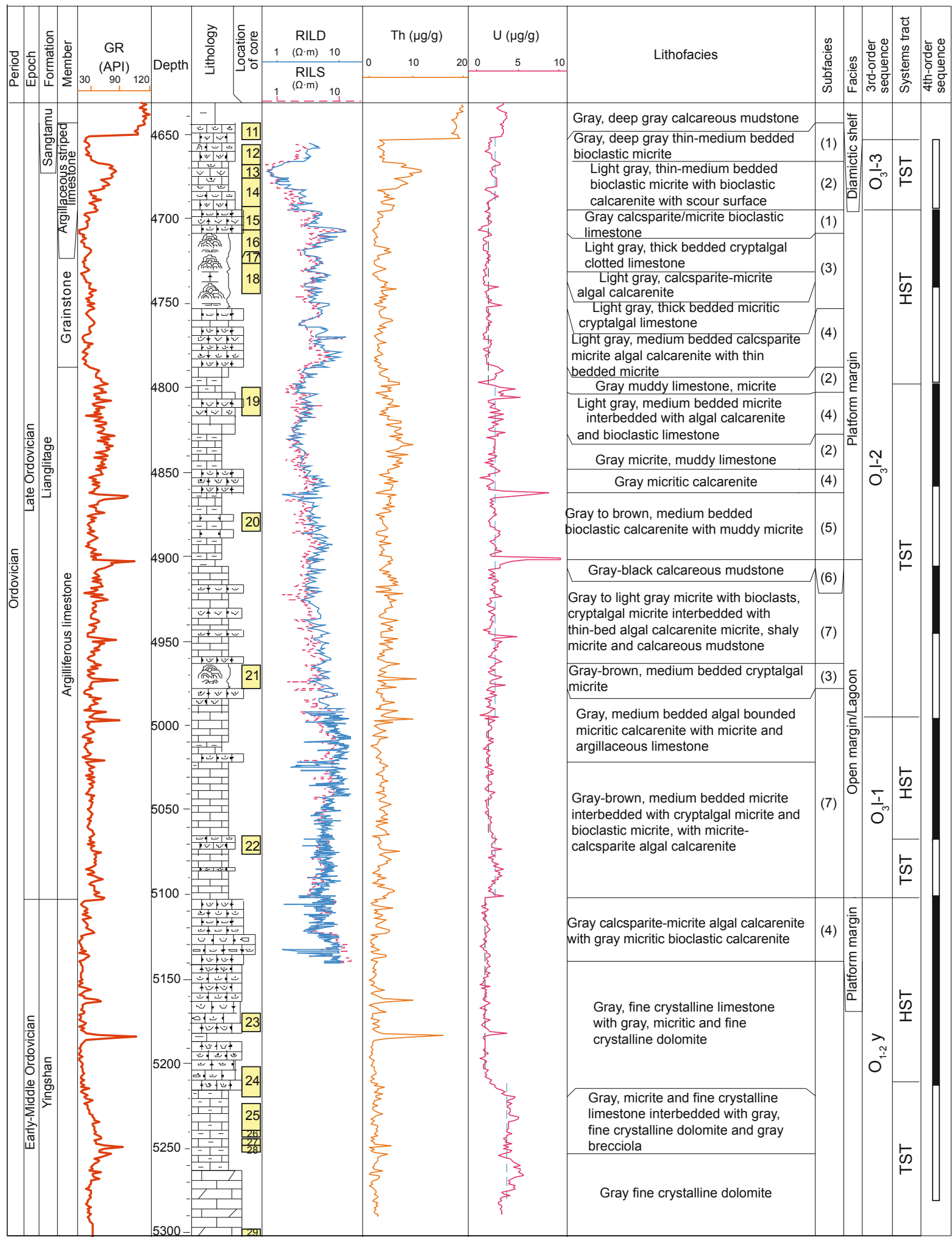

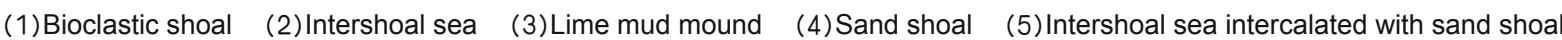
(6) Lowland in platform interior (7) Sand shoal intercalated with intershoal sea

Fig. 3 Ordovician lithology, sedimentary facies and sequence analysis of well TZ12 (see Fig. 5 for lithological legend). Hybrid shelf: mixed carbonate-siliciclastic shelf, HST: highstand systems tract, TST: transgressive systems tract 
the basin and platform interior. It also becomes significantly smaller westward from $882 \mathrm{~m}$ in well TZ43 to $120 \mathrm{~m}$ in well TZ49 (Fig. 8).

\subsection{3rd-order sequence and systems tract}

Sequence boundaries are represented by abrupt changes in physical characteristics and can be identified using well logs and cores. Systems tracts can be identified from the stacking patterns of parasequences or 4th-order sequences.

Analysis of well TZ12 with natural gamma-ray spectrometry logs (Figs. 3 and 4) shows that the contents of uranium (U), thorium (Th), potassium (K), CGR (computed gamma ray) and ratios of $\mathrm{Th} / \mathrm{U}, \mathrm{Th} / \mathrm{K}$ differ in different intervals of the Ordovician. In general, the uranium, thorium and potassium contents of highstand systems tract in each sequence are significantly lower than those of transgressive systems tract.

Three 3rd-order sequences have been identified in the Lianglitage Formation, named $\mathrm{O}_{3} 1-1, \mathrm{O}_{3} 1-2$ and $\mathrm{O}_{3} 1-3$ respectively from bottom to top. Well sections and seismic profiles show that the sequence $\mathrm{O}_{3} 1-1$ and $\mathrm{O}_{3} 1-2$ on the platform are both composed of highstand systems tracts and transgressive systems tracts, but lack lowstand systems tracts (Figs. 3, 4, 5 and 7). Sequence $\mathrm{O}_{3} \mathrm{l}-3$ is a transgressive sequence or drowning sequence, which reflects the platform being submerged by rising relative sea levels (Figs. 2(a) and $7(\mathrm{c})$ ), and lacks both highstand systems tracts and lowstand systems tracts.

The depositional architecture of the platform interior and platform margin of the Lianglitage Formation in the study area seems like a simple layered model. Actually, the
Lianglitage Formation consists of sigmoid clinoforms with foresets that can only display clearly on the high quality seismic profiles in the western area. Some authors (Pomar, 1994; Zeng and Kerans, 2003; Hardage et al, 2006) have done much research on the seismic reflection characteristics of the prograding configuration.

The sequence $\mathrm{O}_{3} 1-1$ is distributed in the platform margin along the No. 1 Fault Belt and in the eastern platform interior (Figs. 7 and 8). This sequence stepped back to the high positions along the unconformable platform surface. The seismic profile of sequence $\mathrm{O}_{3} \mathrm{l}-1$ shows parallel reflection. Along the zone of well TZ35 and TZ12, the sequence $\mathrm{O}_{3} 1-1$ overlaps the eroded slope inside the platform and pinches out to the northwest. The sequence $\mathrm{O}_{3} 1-2$ is $80-600 \mathrm{~m}$ thick. The thickness of the 3rd-order sequence is greatest on the platform margin and slope, and it becomes thinner both basinward and landward. The sequence $\mathrm{O}_{3} 1-3$ is about $20-100 \mathrm{~m}$ thick and is widely distributed on the platform. The sequence $\mathrm{O}_{3} 1-3$ overlaps the slope on the platform landward and westward.

The geometry of sequence $\mathrm{O}_{3} 1-2$ almost determines the geometry of the late Ordovician carbonate platform. There are two basic types of the late Ordovician carbonate platform margin with different geometry and reflection characteristics in the northern slope of Tazhong. One shows that its thickness is maximum at platform margin and becomes smaller rapidly toward the basin and platform interior. Progradation is shown on the seismic data by clinoform geometry in platform margin (Fig. 7(a) and 7(b)). Low-angle sigmoid clinoforms formed in the early stage of highstand systems tract, and high-angle sigmoid clinoforms formed in the late stage. The other shows that the thickest sequence $\mathrm{O}_{3} 1-2$ is at platform margin, but

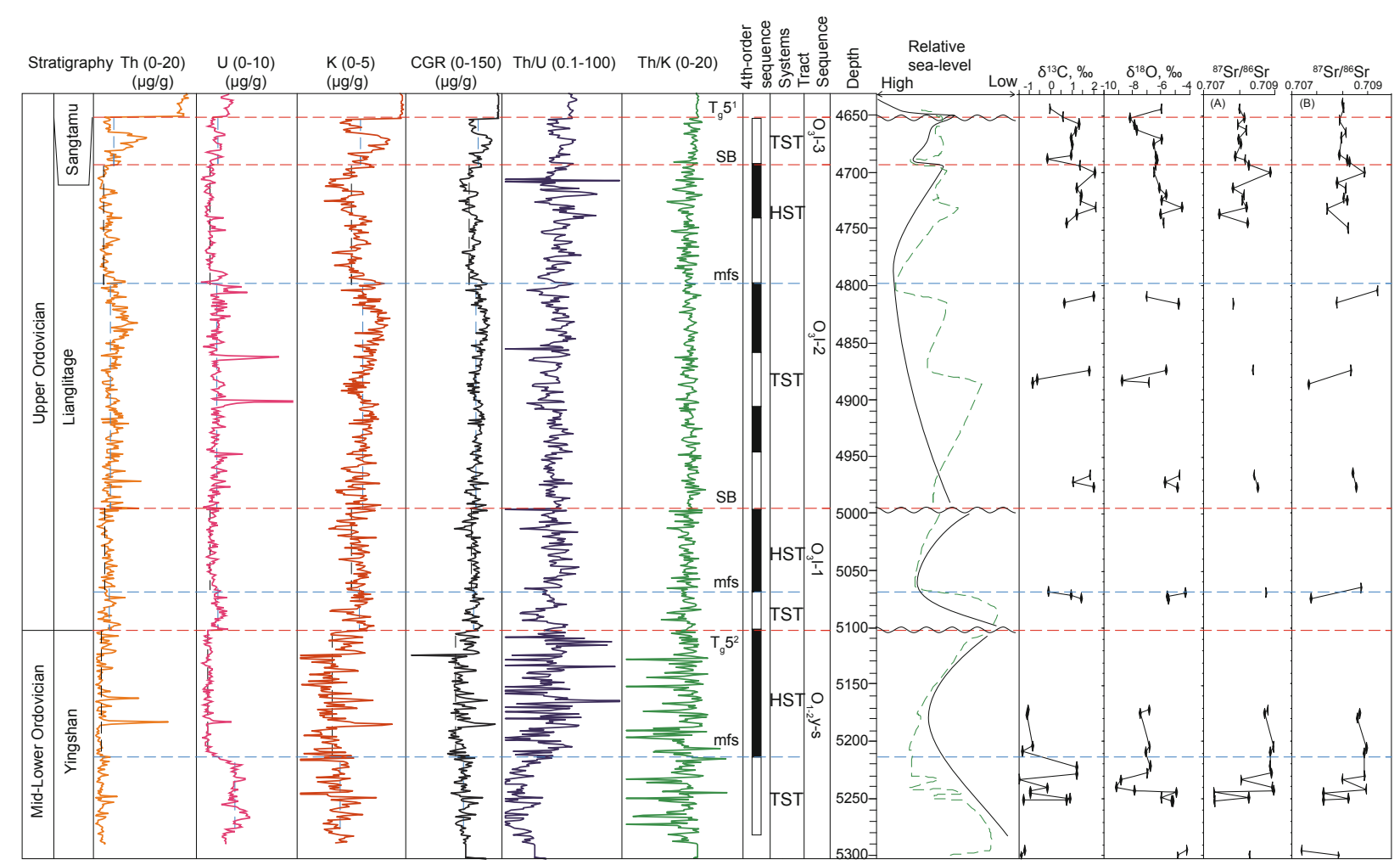

Fig. 4 Ordovician natural gamma-ray spectrometry log curve and carbon, oxygen and strontium isotope data of well TZ12 (Carbon, oxygen and strontium isotope data come from Jiang et al (2001) and Gao et al (2007)) mfs: maximum flooding surface, SB: sequence boundary 


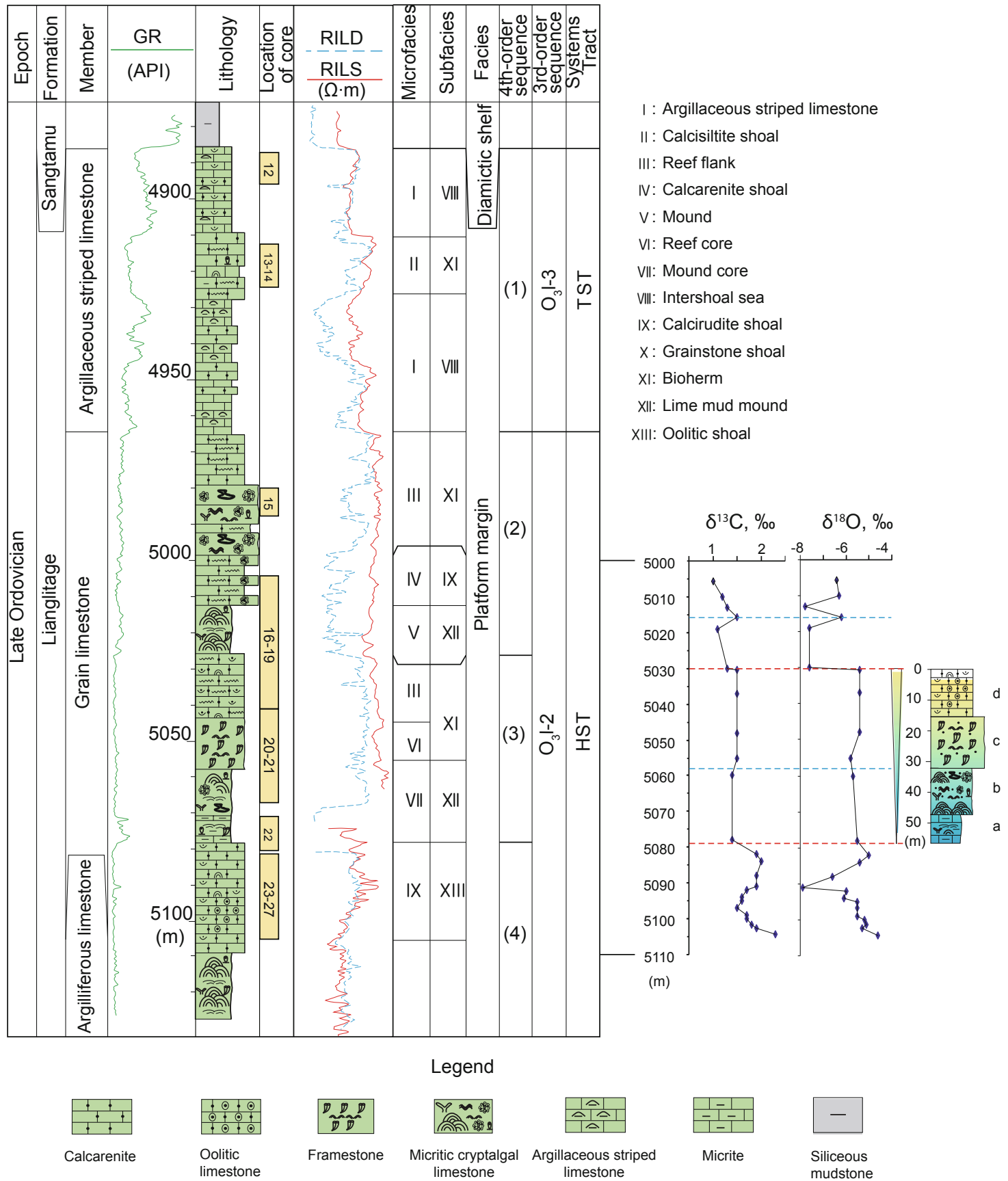

Fig. 5 Sedimentary facies, and the relationship between the 4th-order sequence and carbon/oxygen isotope data of well TZ30

gradually becomes smaller toward the platform interior with parallel seismic events, and pinches out abruptly basinward, forming a steep cliff.

\subsection{4th-order sequence}

The 4th-order sequence can be identified from the stacking patterns of smaller-scale high frequency sequences using cores and log data. According to the lithofacies and sedimentary facies analysis of well TZ30 and TZ12, the 4thorder sequences are easily recognized from the small scale flooding surfaces (Figs. 3, 4 and 5). The 4th-order sequences contain regionally correlative flooding events, overlain by regionally off-lapping shallow water facies. Most 4th-order sequences are asymmetric and have only thin aggradational/ progradational units.

Based on the analysis of lithofacies and depositional cycles, one 4th-order carbonate platform margin sequence comprises small scale shoaling-upwards depositional cycles and can be divided into four units, including mudstone/ micrite, bindstone, framestone and grainstone. However, the platform interior usually lacks framestone. The small scale flooding surface corresponds to mudstone/micrite deposited in relatively deep water. It often occurs at the bottom of the funnel-shaped well logging curves.

The sequence $\mathrm{O}_{3} 1-3$ in the western platform margin is characterized by a backstepping stacking pattern. The 4th- 
order sequence stacking patterns of sequence $\mathrm{O}_{3} \mathrm{l}-2$ and $\mathrm{O}_{3} 1-3$ show retrogradation in transgressive systems tracts and progradation in highstand systems tracts on the platform.

The above analysis shows that the changes in uranium, thorium and potassium contents of the natural gamma-ray spectrometry log can be used to recognize and correlate the 3rd-order sequence, systems tract and 4th-order sequence of carbonate system in the Tazhong region, especially when the seismic resolution is low (dominant frequency is about $15-25$ $\mathrm{Hz})$.

\section{Facies distribution in sequence stratigraphic framework}

\subsection{Lithology and depositional environments in the Lianglitage Formation}

The lithology of the Lianglitage Formation consists of grainstone, wackestone, packstone, micrite, argilliferous limestone, argillaceous striped limestone, and bioherm (Fig. 6). Grains include lime sands with variable grain size, ooids, bioclasts, oncoliths and algae clot, and are excellently sorted. The percentage of grains to total rock volume is $50 \%$ $90 \%$. Grains are cemented by sparry calcite. Grainstone and oosparite have a large proportion of potential intergranular pores.

The representative fossils consist of corals, sponges, stromatoporoids, receptaculitids, solenopora, as well as their complex, which are characterized by light gray massive structure, well-developed framework holes and ostracods filled in them. Besides, there are several conodonts, including Aphelognathus pyramidalis, Belodina compressa, Phragmidus undatus, Plectodina bidentata, Pseudobelodina dispansa, P. bullhillensis and Yaoxianognathus lijiapoensis.

The major sedimentary facies of the Lianglitage
Formation include reef flats in the platform margin and lagoon in platform interior, and are subdivided into coralsponge-stromatoporoid reef complex, sand shoal, lime mud mound, intershoal sea and lowland. The complex of reef and sand shoal including sparry grainstone and reef, mainly develop in the platform margin, indicating the high-energy hydrodynamic conditions. In addition, only some patch reef and its related sand shoal develop at low relief in platform interior, indicating relatively lower energy hydrodynamic conditions. Intershoal sea deposits usually develop between the sand shoals and are dominated by micrite, interbedded with mudstone. It indicates a relative low-energy environment. Lime mud mound consists of light gray bedded cryptalgal clotted limestone interbedded with wackestone or packstone, indicating low-energy hydrodynamic conditions. Lowland develops in platform interior and is dominated by muddy micrite and mudstone, indicating low-energy hydrodynamic conditions. Reef, sand shoal and their complex often develop favorable primary pores and are potential reservoir facies.

Based on the analysis of lithofacies and depositional cycles, one 4th-order sequence of carbonate platform margin comprises small scale shoaling-upwards depositional cycles and can be divided into four units from bottom to top, including a, b, c and d (Fig. 5). Unit a is mainly micrite (Fig. 6(d)), approximately $10 \mathrm{~m}$ thick, and is infiltrated by marine clay. Unit $b$ is algal bindstone, about $10-15 \mathrm{~m}$ thick. Unit $\mathrm{c}$ is framestone (Fig. 6(e)) interbedded with some grainstone, approximately $10-15 \mathrm{~m}$ thick. Unit $\mathrm{d}$ is mainly sparry grainstone (Fig. 6(a) and (b)), 15-20 m thick, including calcisiltite, calcarenite, calcirudite, oolite and their interbeds with different thickness. The corresponding depositional environment of these four units from bottom to top is lime mud mound, algal reef, framestone, and sand shoal/oolitic shoal/bioclastic shoal.
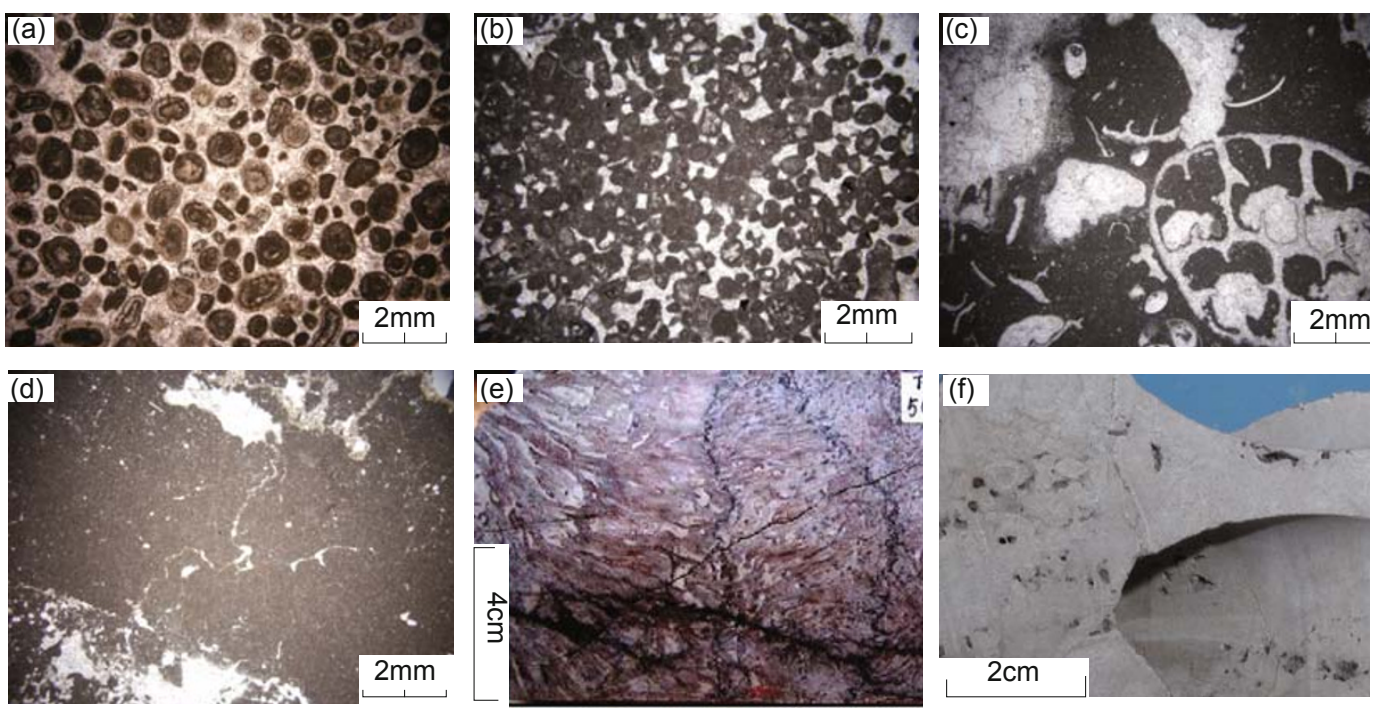

Fig. 6 Photographs of cores and thin sections showing the main types of carbonate rocks of the Lianglitage Formation of well TZ30 (a) Sparry oolitic limestone, plane polarized light; (b) Sparry grainstone, plane polarized light; (c) Bioclastic limestone, plane polarized light; (d) Micrite, plane polarized light; (e) Coral framestone; (f) Grainstone with millimeter-scale holes 


\subsection{Distribution of reefs and sand shoals}

Firstly, we established the corresponding relationship between seismic properties and lithology using the cores and well logs. Then, based on the relationship between synthetic seismic records and well logs, the external geometry and internal reflection configuration of the 3-D seismic dataset were studied using the theory of seismic stratigraphy. In order to reveal the temporal and spatial evolution of the facies of the Lianglitage Formation in sequence stratigraphic framework, seismic sedimentology has been applied, and some new technologies, such as stratal slice, seismic attribute analysis and paleogeomorphology recovering, have also been introduced.

Fig. 7 shows two seismic profiles and a well-correlation panel across wells Z11-TZ63-TZ88. Fig. 7(b) is the processed seismic profile from the original one (Fig. 7(a)), flattened along the siliceous mudstone surface when the platform was just buried. The flattened seismic profile reconstructs a more realistic platform before tectonic deformation. Seismic facies of the complex of reef and sand shoal display moderate to low amplitude reflections, and sigmoid progradational or shingled reflection configuration appears in the zone of well TZ85 and TZ86. Fig. 7(c) shows the complex of reef and sand shoal mainly developed in the zone of well TZ88 near the No. 1 Fault Belt. Patch reef and packstone can be found in platform interior, and the drilling of well TZ63 proves it. The sequence $\mathrm{O}_{3} 1-1$ pinches out near the well TZ63. The sand shoal of highstand systems tract in the sequence $\mathrm{O}_{3} 1-2$ also develops in the platform interior. The reefs in the sequence $\mathrm{O}_{3} \mathrm{l}-3$ migrate to high positions and form retrograding reefs in the western platform and low relief in the platform interior.

Fig. 8 shows a well-correlation panel along the platform interior from northwest to southeast. This panel mainly reveals the sand shoal distribution in the sequence framework. The sand shoal in the sequence $\mathrm{O}_{3} 1-1$ develops at the top of the highstand systems tract. The thickness of the transgressive systems tract in sequence $\mathrm{O}_{3} 1-2$ changes significantly near the well 12 and well 162. The sand shoal develops near the slope. The sand shoal of the highstand systems tract in the sequence $\mathrm{O}_{3} \mathrm{l}-2$ is widespread in the platform interior, and only in the well TZ35 can the patch reef be found in this interval. The sand shoal and patch reef in the sequence $\mathrm{O}_{3} \mathrm{l}-2$ are very thin, and only develop in the upper part.

The seismic profile across wells Z11T-TZ63-TZ88 in Fig. 7(a) and 7(b), root-mean-square (RMS) amplitude map (Fig. 9(a)) and seismic facies map (Fig. 9(b)) show that seismic reflections change laterally from continuous to discontinuous and more hummocky, as well as from parallel to sigmoid and shingled toward the platform margin.

The sedimentary facies map of sequence $\mathrm{O}_{3} \mathrm{l}-2$ (Fig. 9(b)) was established on the basis of the relationship of the RMS amplitude map (Fig. 9(a)), well logs and cores. The maps show that the low-amplitude part represents the complex of reef and sand shoal along the platform margin. The width of the complex of reef and sand shoal along the No. 1 Fault Belt is $1-5 \mathrm{~km}$. The complex is wider in the zone from well TZ86 to well TZ85 and from well TZ82 to well TZ161. In the sequence $\mathrm{O}_{3} 1-2$, the reefs along the No. 1 Fault Belt are prograding reefs near the zone from well TZ85 to TZ86 in the western platform and the zone from well TZ82 to TZ26. The reef near the zone of well TZ68 in the central platform is an aggrading type. There are about 3-6 reef complexes, which consist of several reef bodies superimposed vertically and laterally. Moderate-amplitude part near the zone of well TZ12 and TZ162 in the platform interior represents the sand shoal. In the zone of well TZ12, TZ80 and TZ162, sand shoals with good reservoir properties have been found in this interval.

In conclusion, the analysis based on seismic facies and depositional architecture of the carbonate platform of the Lianglitage Formation shows that seismic facies with wedgelike geometry and discontinuous prograding configuration are always corresponding to the complex of reef and sand shoal. Sand shoal develops on the slope in the platform interior due to the antecedent palaeotopography.

\section{Late Ordovician sea-level fluctuation and factors controlling sequences and facies}

\subsection{Reconstruction of late Ordovician sea-level fluctuation curve}

Some authors (Jiang et al, 2001; Bao et al, 2006; Gao et al, 2007) have independently established relative sea-level curves based on the analysis of carbon, oxygen and strontium stable isotopes measured from limited core samples. However, natural gamma-ray spectrometry log data provide a continuous record and fill the gap in core recovery. Based on previous study of depositional cycles and natural gammaray spectrometry log data of the Lianglitage Formation in the northern slope of the Tazhong Uplift, the more accurate relative sea-level fluctuation curve has been established (Fig. 4).

Fig. 4 shows the natural gamma-ray spectrometry log of well TZ12. It indicates that the contents of uranium (U), thorium (Th), potassium (K), CGR and ratios of $\mathrm{Th} / \mathrm{U}$ and $\mathrm{Th} / \mathrm{K}$ in different intervals of the mid-late Ordovician vary significantly (Table 1). In the uppermost sequence of the Yingshan Formation, the thorium, uranium and potassium contents of the highstand systems tract are minimum, about $1.19 \mu \mathrm{g} / \mathrm{g}, 0.49 \mu \mathrm{g} / \mathrm{g}$ and $0.40 \%$, respectively. In the sequence $\mathrm{O}_{3} \mathrm{l}-1$ and $\mathrm{O}_{3} \mathrm{l}-2$, the thorium, uranium and potassium contents of the transgressive systems tracts are obviously higher than those of the highstand systems tracts. The thorium, uranium and potassium contents of the sequence $\mathrm{O}_{3} 1-3$ are high, but less than those of the lowest part of the Sangtamu Formation, which has the highest contents, up to $14.16 \mu \mathrm{g} / \mathrm{g}, 2.66 \mu \mathrm{g} / \mathrm{g}$ and $3.3 \%$, respectively. The cyclic changes reflected in natural gamma-ray spectrometry logs are consistent with the variations of systems tracts. Besides, smaller scale changes of natural gamma-ray spectrometry logs can be identified. Thus, these changes are interpreted to indicate sea-level changes on several orders of scale.

The uranium, thorium and potassium contents of the natural gamma-ray spectrometry log can be used to estimate 

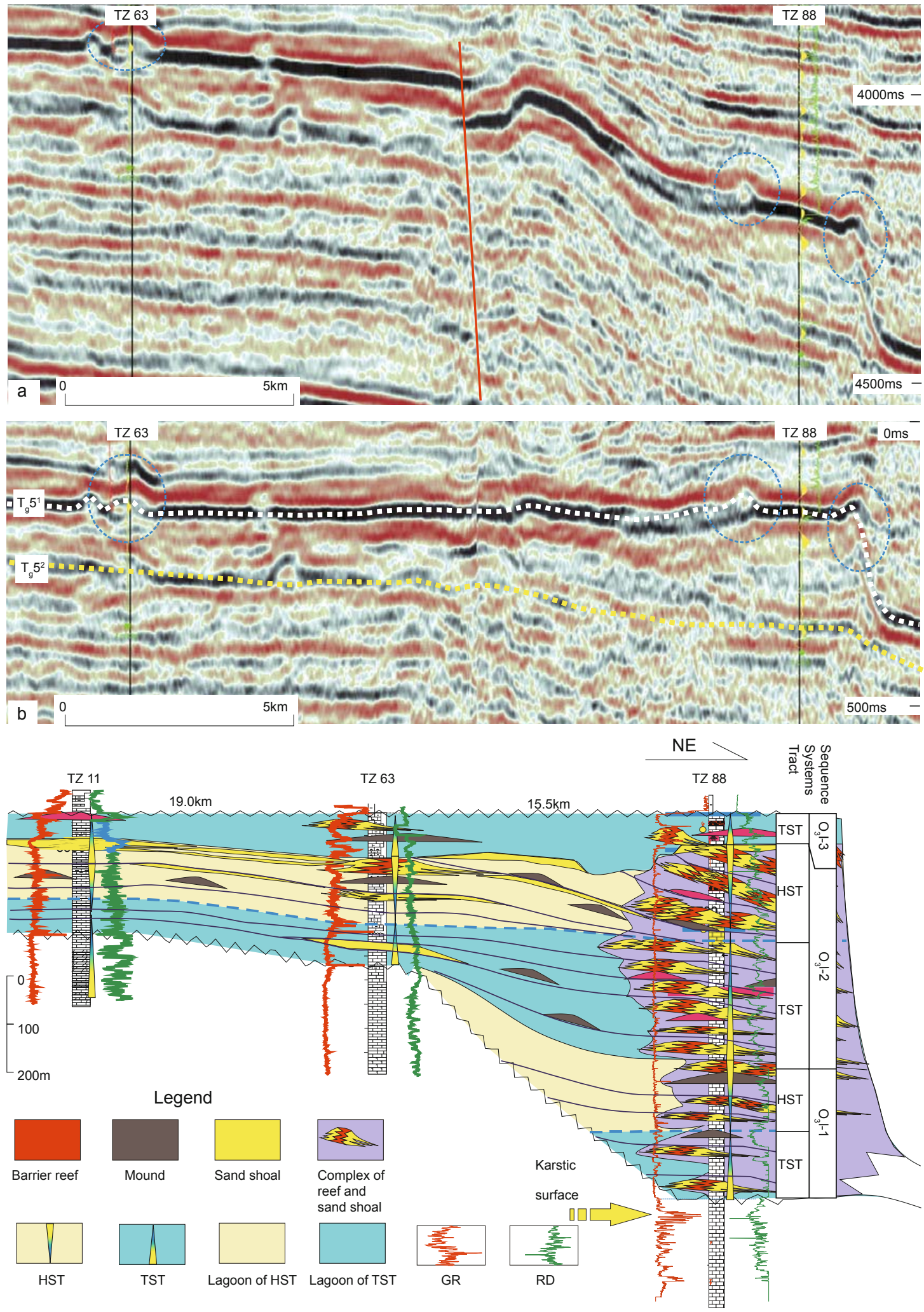

Fig. 7 (a) Seismic profile across well TZ63 and TZ88 (gamma-ray curve and synthetic seismic record are marked on it); (b) Seismic profile flattened along the mudstone surface when the platform was just buried; (c) Interpretation of sequences and facies of the Lianglitage Formation. See Fig. 1 for the location of seismic profile and wells. GR: natural gamma-ray log; RD: resistivity log

the siliceous mud content. There is a good linear relationship between the content of siliceous mud and that of thorium/ potassium (Ding, 1994). Besides, the Th/U and Th/K ratios can be applied to analyze the ancient sedimentary environment and relative water depth. The above result reveals that the carbonate content of the highstand systems tract is higher than that of the transgressive systems tract (Figs. 3 and 4). 


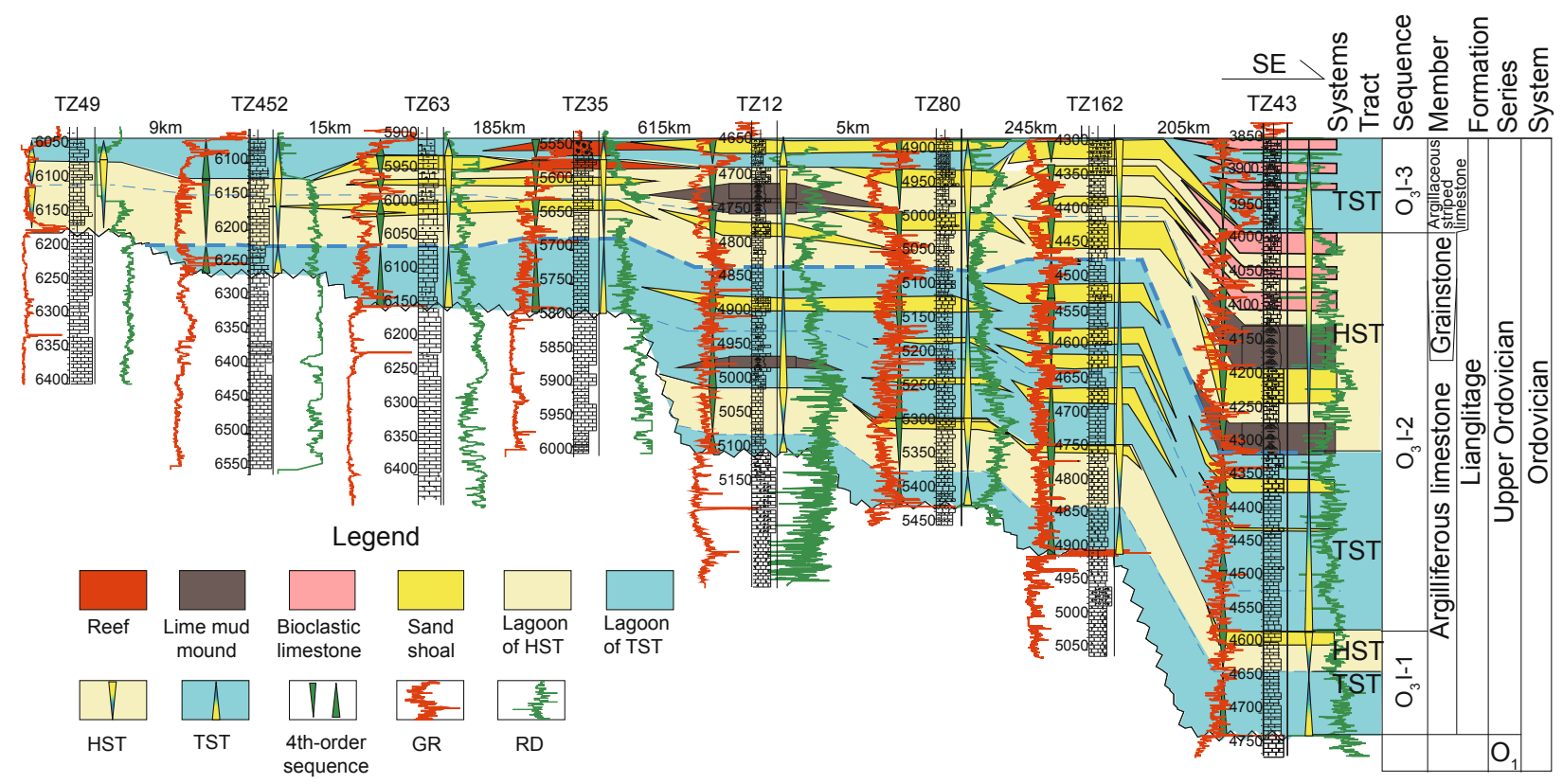

Fig. 8 Sequences, systems tracts, 4th-order sequences and facies interpreted on the GR-resistivity-log section. See Fig. 1 for the location of wells

Table 1 Contents of natural gamma-ray spectrometry log in each systems tract of Well Tazhong 12

\begin{tabular}{|c|c|c|c|c|c|c|}
\hline $\begin{array}{lr}\begin{array}{c}\text { Natural gamma-ray } \\
\text { spectrometry }\end{array} \\
\text { Systems tracts }\end{array}$ & $\begin{array}{c}\mathrm{TH} \\
\mu \mathrm{g} / \mathrm{g}\end{array}$ & $\begin{array}{c}\mathrm{U} \\
\mu \mathrm{g} / \mathrm{g}\end{array}$ & $\begin{array}{l}\mathrm{K} \\
\%\end{array}$ & $\mathrm{Th} / \mathrm{U}$ & $\mathrm{Th} / \mathrm{K}$ & $\begin{array}{c}\text { CGR } \\
\mu \mathrm{g} / \mathrm{g}\end{array}$ \\
\hline Bottom of $\mathrm{O}_{3} \mathrm{~s}$ & 14.16 & 2.66 & 3.30 & 5.40 & 4.29 & 117.21 \\
\hline $\mathrm{O}_{3} 1-3-\mathrm{TST}$ & 3.76 & 1.30 & 1.06 & 3.06 & 3.55 & 35.78 \\
\hline $\mathrm{O}_{3} 1-2-\mathrm{HST}$ & 1.76 & 0.77 & 0.66 & 5.11 & 2.71 & 19.73 \\
\hline $\mathrm{O}_{3} 1-2-\mathrm{TST}$ & 3.00 & 1.60 & 0.98 & 2.57 & 3.10 & 31.09 \\
\hline $\mathrm{O}_{3} 1-1-\mathrm{HST}$ & 1.91 & 0.92 & 0.73 & 2.44 & 2.62 & 21.60 \\
\hline $\mathrm{O}_{3} 1-1-\mathrm{TST}$ & 2.34 & 1.74 & 0.87 & 1.65 & 2.90 & 26.08 \\
\hline $\mathrm{O}_{1-2} \mathrm{y}$ & 1.19 & 0.49 & 0.40 & 4.30 & 2.75 & 12.45 \\
\hline
\end{tabular}

The carbon and strontium isotopic composition are of global significance and are useful tools for studying global events and stratigraphic correlation (Veizer et al, 1999; Jiang et al, 2001; Huang et al, 2004). The carbon and strontium isotopes of unaltered Ordovician marine carbonates in the Tazhong Uplift represent those of primary seawaters. Their evolution trends are consistent with the global evolution curve (Yu et al, 2001; Jiang et al, 2001; Huang et al, 2004).

In addition, 25 unaltered rock samples were collected from the well TZ30 at the depth of 5,005-5,110 m (Fig. 5). Carbon and oxygen isotope analyses were carried out at the Isotope Laboratory of Ministry of Land and Resources, Chinese Academy of Geological Sciences. The isotopic ratios were reported in \%o according to the PDB standard. Fig. 6 shows that the values of $\delta^{13} \mathrm{C}$ in unit a and unit $\mathrm{b}$ are less than those in unit $\mathrm{c}$ and unit $\mathrm{d}$ in the 4th-order sequence. In addition, natural gamma-ray spectrometry logs are also very useful in recognizing the 4th-order sequences (Fig. 4). Carbon and oxygen stable isotope analysis shows that one 4th-order sequence represents a cyclic event of rapid rise (records a and b) after decline of relative sea-level, and then in a relatively stable stage (records c and d).

Based on the sea-level curves in Fig. 4, three 3rd-order and at least six 4th-order sea-level fluctuations have been recognized in late Ordovician. Longer and larger fluctuations are modulated by lesser ones of higher frequency. The 4thorder sequence is a response to the 4th-order sea-level change (dashed line of sea-level curve in Fig. 4) and represents a cyclic event of a rapid rise stage after decline of relative sealevel, and then in a relatively stable stage. The 3rd-order sequence is a response to the 3rd-order sea-level change (solid line of sea-level curve in Fig. 4). During the late Ordovician, the global sea-level rose rapidly until the end of the late Ordovician (the Sangtamu Formation deposition). At the same time, the Tazhong carbonate platform was drowned completely, and then buried by terrigenous material.

\subsection{Controlling factors of the formation of late Ordovician carbonate sequence and facies}

Based on the above analysis, it is possible to compare 


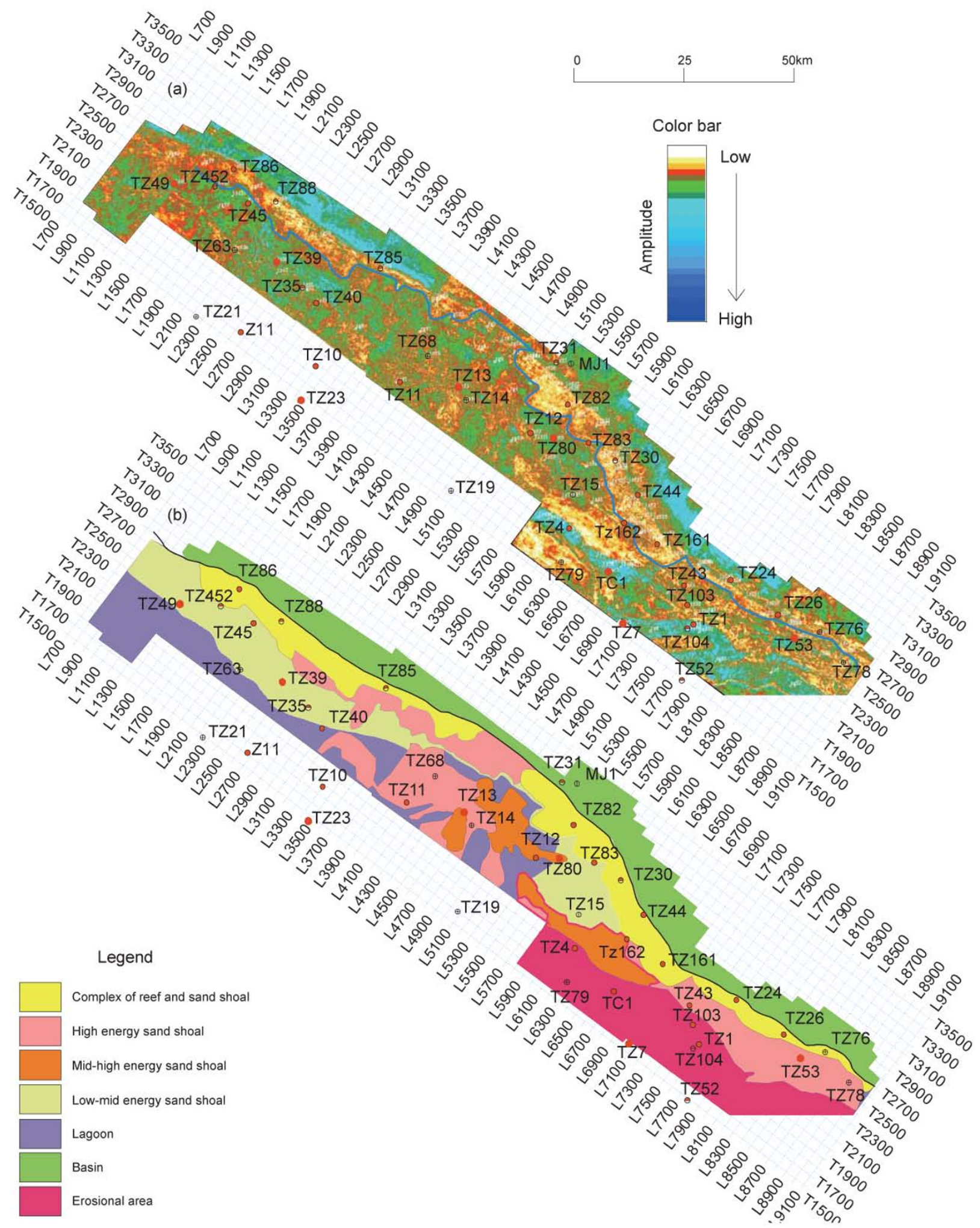

Fig. 9 RMS amplitude map (a) and sedimentary facies map (b) of the sequence $\mathrm{O}_{3} \mathrm{l}-2$

the depositional architecture of the carbonate platform with similar depositional environments in the Tazhong region. The model of sequences and depositional architecture of the late Ordovician drowned carbonate platform in the northern slope of the Tazhong Uplift is established (Fig. 10). This model can be used to refine the interpretation of seismic data in terms of facies distribution and relative sea-level history, and to analyze and predict facies and reservoirs. Hence, from the genetic point of view, the following discussions focus on the responses of carbonate sedimentation to sea-level changes, 
including sedimentary sequences, facies, and their evolution.

The growth of the reefs was always accompanied by the development of lime sand shoals on the rimmed carbonate platform margin. The growth pattern of the reefs determined the characteristics of the complex of reef and sand shoal. The reefs migrating laterally basinward (HST shown in Figs. 7 and 10) and pure carbonate rock both characterize highstand systems tract, and show that the relative sea-level rises very slowly. In this stage, the growth rate of carbonate rock in the platform margin exceeds the rate of sea-level rise, and the complex of reef and sand shoals develop rapidly. Only patch reefs and small scale sand shoals develop in the platform interior, which indicate that the rate of relative sea-level rise exceeds the carbonate growth rate. In the sequence $\mathrm{O}_{3} 1-2$, the shingled prograding stacking pattern of the 4th-order sequences (HST2 shown in Fig. 10) or the horizontal growth of reefs represent the late stage of highstand systems tract and imply a relative stillstand sea-level stage.

The migration of reefs towards high land and impure carbonate rock both indicate transgressive systems tract and suggest that the relative sea-level rise is fast. The rate of sealevel rise exceeds the growth rate of carbonate rock in the platform interior and margin, until the platform top becomes deeply submerged. The carbonate rock is impure in this stage.

Erosional truncation and epidiagenetic karstification represent the falling of the relative sea-level. It caused the exposure of parts of the platform, thereby the vertical aggradation strata were eroded and the exposed areas underwent meteoric diagenesis. The cores of many wells along the platform margin, such as wells TZ26, TZ30, TZ44, TZ45, TZ62, TZ82, and TZ161, show that intragranular pores, intergranular pores, moldic pores and vug are common in the meteoric vadose and phreatic zones near the exposed surface. The average porosity of these wells is $1.3 \%-7.4 \%$ and permeability is relatively high. The porosity of the transgressive systems tracts and the lower parts of the 4thorder sequences is poor, because the pores are cemented by calcsparite. Micrite, argilliferous limestone and argillaceous striped limestone in the platform interior rarely developed good reservoirs. During the large scale sea-level fall, however, the upper part of the highstand systems tracts or the 4th-order sequences in the platform interior suffered subaerial exposure over long periods and metastable sediments could be leached by meteoric waters.

Based on the analysis of depositional architecture in response to the relative sea-level changes, the evolution of the late Ordovician carbonate platform in the northern slope of the Tazhong Uplift is a drowning event (Fig. 10). In addition, the antecedent palaeotopography controls the dominant distribution of sand shoal and reef in the platform.

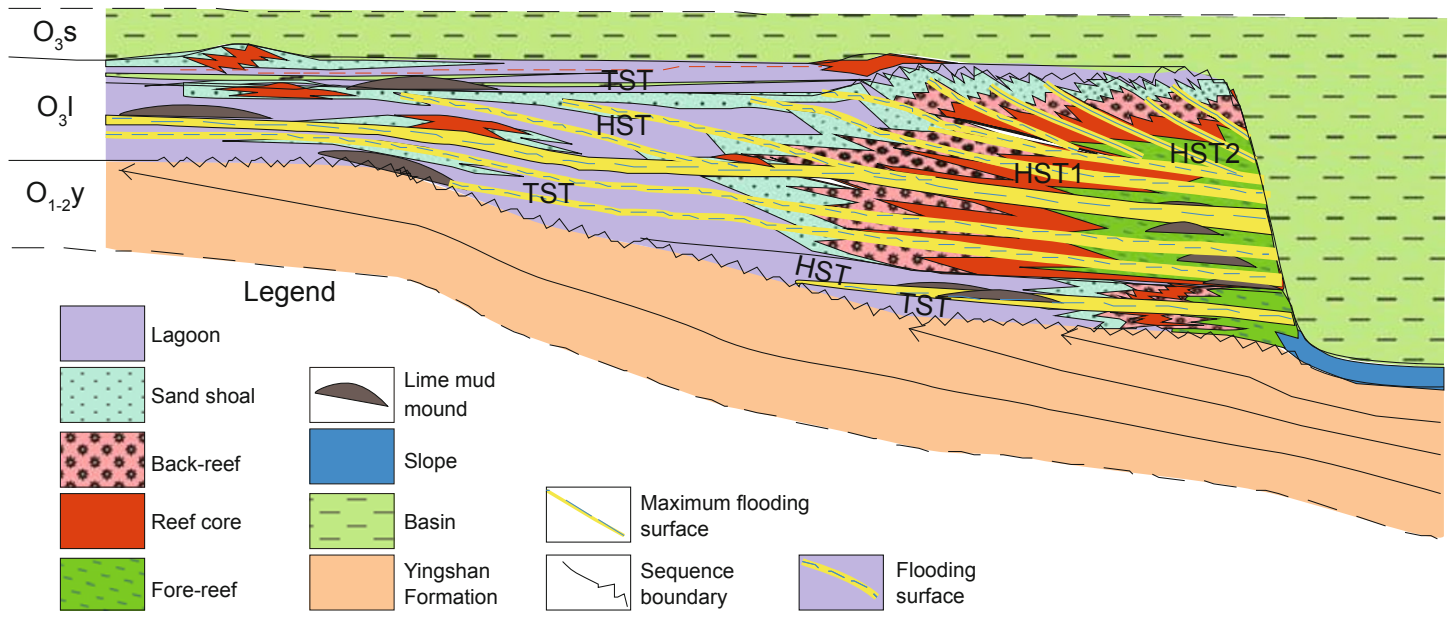

Fig. 10 Model of sequences and depositional architecture of the late Ordovician drowned carbonate platform, the northern slope of the Tazhong Uplift

\section{Discussion \& conclusions}

1) The Lianglitage Formation in the northern slope of the Tazhong Uplift can be divided into one 2nd-order, three 3rdorder and several 4th-order sequences. The late Ordovician relative sea-level fluctuation curve is established. The value changes in uranium, thorium and potassium contents of the natural gamma-ray spectrometry log are very effective for recognizing the 3rd-order sequences, systems tracts and 4thorder sequences of the carbonate system in the Tazhong region.

However, it is worth noting that the late Ordovician carbonate platform in the Tazhong region only has the depositional records of highstand and transgressive systems tracts, but lacks records of lowstand systems tracts. Therefore, the relative sea-level fluctuation curve based on various data still lacks the corresponding information of lowstand systems tracts. In other words, the late Ordovician relative sea-level fluctuation curve in the study area is not complete.

2) Major sedimentary facies of the Lianglitage Formation include reef and shoal in the platform margin and lagoon in the platform interior, which can be further subdivided into coral-sponge-stromatoporoid reef complex, sand shoal, lime mud mound, and intershoal sea. Reefs, sand shoals and their complex are favorable facies for reservoirs. The reefs and sand shoals in the sequence $\mathrm{O}_{3} \mathrm{l}-1$ and $\mathrm{O}_{3} \mathrm{l}-2$ developed in the upper sections of their highstand systems tract. The sand shoals in the sequence $\mathrm{O}_{3} \mathrm{l}-2$ developed in transgressive 
systems tract and are widespread at the slope in the platform interior. The platform margin with the wedge-like geometry and the prograding configuration is a response to the lateral shifting of the reef and sand shoal complex. The reefs in the sequence $\mathrm{O}_{3} \mathrm{l}-3$ formed retrograding reefs in the western platform and low relief in the platform interior.

3) The relative sea-level fluctuation and antecedent palaeotopography control the development and distribution of the reef complex and unconformity karst zone. The evolution of the late Ordovician in the northern slope of the Tazhong Uplift shows a drowning event. The characteristics of reef migration are responses to the relative sea-level changes. Antecedent palaeotopography controls the dominant distribution of the sand shoals and reefs on the platform.

4) Exploration shows that the composite zone of epidiagenetic karstic intervals and high-energy complex of reef and sand shoal with prograding configuration can form effective reservoirs. In addition, sand shoals of good reservoir quality can be found in the slope of the platform interior. Sealed by the lagoonal micrite or/and terrigenous mudstone, they serve as potential oil-gas reservoir intervals. Composite stratigraphic traps are an important target for oil and gas exploration in the northern slope of the Tazhong carbonate platform. Locating this zone along the northern slope in the platform and the similar areas in the Tarim Basin is still significant.

\section{Acknowledgements}

This research is supported by the National Key Basic Research and Development Program of China (Grant No. 2006CB202302). We also appreciate Exploration and Development Research Institute of PetroChina Tarim Oilfield Company for its support to this study.

\section{References}

Bao Z D, Jin Z J, Sun L D, et al. Sea-level fluctuation of the Tarim Area in the Early Paleozoic: Response from geochemistry and karst. Acta Geologica Sinica. 2006. 80(3): 366-373 (in Chinese)

Chen S P, Wang Y and Jin Z J. Controls of tectonics on both sedimentary sequences and petroleum systems in Tarim Basin, northwest China. Petroleum Science. 2007. 4(2): 1-9

Chen X J, Cai X Y, Xu X H, et al. The research on sedimentation features in Cambrian-Ordovician sequence frame in the center of the Tarim Basin. Xinjiang Geology. 2006. 24(3): 276-280 (in Chinese)

Chen X, Zhao Z J, Zhang B M, et al. Sedimentary model to Lianglitage Formation of Upper Ordovician in the northern margin of isolated platform in the center of the Tarim Basin. Acta Sedimentologica Sinica. 2009. 27(5): 1002-1011 (in Chinese)

Ding C Q. Field Geophysics. Beijing: Petroleum Industry Press. 1994. 116-137 (in Chinese)

Eberli G P, Masaferro J L and Sarg J F. Seismic imaging of carbonate reservoirs and systems. In: Eberli G P, Masaferro J L and Sarg J F (eds.). Seismic Imaging of Carbonate Reservoirs and Systems. AAPG Memoir 81. 2004. 1-9

Feng Z Z, Bao Z D, Wu M B, et al. Lithofacies palaeogeography of the Ordovician in Tarim area. Journal of Palaeogeography. 2007. 9(5): 447-460 (in Chinese)

Gao Z Y, Zhang S C, Zhu R K, et al. Sea-level change and heterogeneity of source rocks of Lianglitage Formation in the central Tarim area. Acta Petrolei Sinica. 2007. 28(5): 45-50 (in Chinese)
Gu J Y, Zhang X Y, Luo P, et al. Development characteristics of organic reef-bank complexes on Ordovician carbonate platform margin in the Tarim Basin. Oil \& Gas Geology. 2005. 26(3): 277-283 (in Chinese)

Hardage B A, Remington R L and Murray P E. Reflections have a 'tipper point'. AAPG Explorer. 2006. 27(9): 32

He D F, Zhou X Y, Zhang C J, et al. Tectonic types and evolution of Ordovician proto-type basins in the Tarim region. Chinese Science Bulletin. 2007. 52(S1): 164-177

Huang S J, Shi H, Zhang M, et al. Application of strontium isotope stratigraphy to dating Ordovician marine sediments-A case study from the well Tazhong12 in Tarim Basin. Acta Sedimentologica Sinica. 2004. 22(1): 1-5 (in Chinese)

Jia C Z. Tectonic Characteristics and Petroleum in the Tarim Basin of China. Beijing: Petroleum Industry Press. 1997. 1-4, 277-290 (in Chinese)

Jiang M S, Zhu J Q, Chen D Z, et al. Carbon and strontium isotope variations and responses to sea-level fluctuations in the Ordovician of the Tarim Basin. Science in China (Series D: Earth Sciences). 2001. 44(9): 816-823

Kang J W, Tian J C and Lin X B. Study of the sequence based lithofacies - paleogeography map of Lianglitage Formation in the central Tarim low salient. Journal of Xi'an Shiyou University (Natural Science Edition). 2010. 25(1): 29-34 (in Chinese)

Li Y, Hu Y L, Li B Z, et al. Deliverability of wells in carbonate gas condensate reservoirs and the capillary number effect. Petroleum Science. 2009. 6(1): 51-56

Lin C S, Liu J Y, Liu L J, et al. High resolution sequence stratigraphy analysis: construction of chronostratigraphic sequence framework on facies and reservoir scale. Geoscience. 2002. 16(3): 276-281 (in Chinese)

Lin C S, Yang H J, Liu J Y, et al. Paleostructural geomorphology of the Paleozoic central uplift belt and its constraint on the development of depositional facies in the Tarim Basin. Science in China (Series D: Earth Sciences). 2009. 52(6): 823-834

Lü X X, Yang H J, Yang N, et al. Further recognition of the petroleum exploration potential of marine carbonates in the western Tarim Basin. Petroleum Science. 2007. 4(3): 21-25

Lü X X, Yang N, Zhou X Y, et al. Influence of Ordovician carbonate reservoir beds in the Tarim Basin by faulting. Science in China (Series D: Earth Sciences). 2008. 51(S2): 53-60

Pomar L. High-resolution sequence stratigraphy in prograding Miocene carbonates: Application to seismic interpretation. In: Loucks R G and Sarg J F (eds.). Carbonate Sequence Stratigraphy. AAPG Memoir 57. 1994. 389-407

Sarg J F. Carbonate Sequence Stratigraphy. In: Wilgus C K, Hastings B S, Kendall C G, et al (eds.). Sea-level changes: An integrated approach. SEPM Special Publication 42. 1998. 155-181

Schlager W. Sedimentology and Sequence Stratigraphy of Reefs and Carbonate Platforms. AAPG Continuing Education Course Note Series No.34. 1992. 1-10

Vahrenkamp V C, David F, Duijndam P, et al. Growth architecture, faulting, and karstification of a middle Miocene carbonate platform, Luconia Province, offshore Sarawak, Malaysia. In: Eberli G P, Masaferro J L and Sarg J F (eds.). Seismic Imaging of Carbonate Reservoirs and Systems. AAPG Memoir 81. 2004. 329-350

Vail P R, Bowman S A, Eisner P N, et al. The stratigraphic signatures of tectonics, eustasy and sedimentology-An overview. In: Einsele, Cyclesand Events in Stratigraphy. Berlin Heidelberg: SpringerVerlag. 1991. 617-659

Veizer J, Ala D, Azmy K, et al. ${ }^{87} \mathrm{Sr} /{ }^{86} \mathrm{Sr}, \delta^{13} \mathrm{C}$ and $\delta^{18} \mathrm{O}$ evolution of Phanerozoic seawater. Chemical Geology. 1999. 161(1-3): 59-88

Xu X S, Wang Z J, Wan F, et al. Tectonic paleogeographic evolution and source rocks of the Early Paleozoic in the Tarim Basin. Earth Science Frontiers. 2005. 12(3): 49-57 (in Chinese) 
Yang H J, Liu S, Li Y P, et al. Carbonate reservoir characteristics of upper-middle Ordovician in the Tazhong area, Tarim Basin. Marine Origin Petroleum Geology. 2000. 5(1-2): 73-83 (in Chinese)

Yu B S, Chen J Q and Lin C S. Cambrian-Ordovician sequence stratigraphy on the northern Tarim Platform and its correlation with the Yangtze Platform and North China Platform. Science in China (Series D: Earth Sciences). 2001. 44(4): 373-384

Zeng H L and Ambrose W A. Seismic sedimentology and regional depositional systems in Mioceno Norte, Lake Maracaibo, Venezuela. The Leading Edge. 2001. 20(11): 1260-1269

Zeng H L and Kerans C. Seismic frequency control on carbonate seismic stratigraphy: A case study of the Kingdom Abo sequence, West Texas. AAPG Bulletin. 2003. 87(2): 273-293

Zhang B M and Liu J J. Classification and characteristics of karst reservoirs in China and related theories. Petroleum Exploration and Development. 2009. 36(1): 12-29 (in Chinese)

Zhang J L, Qin L J and Zhang Z J. Depositional facies, diagenesis and their impact on the reservoir quality of Silurian sandstones from the
Tazhong area in the central Tarim Basin, western China. Journal of Asian Earth Sciences. 2008. 33(1-2): 42-60

Zhao W Z, Zhu G Y, Zhang S C, et al. Relationship between the later strong gas-charging and the improvement of the reservoir capacity in deep Ordovician carbonate reservoir in Tazhong area, Tarim Basin. Chinese Science Bulletin. 2009. 54(17): 3076-3089

Zhao Z J, Chen X, Pan M, et al. Milankovitch cycles in the Upper Ordovician Lianglitage Formation in the Tazhong-Bachu Area, Tarim Basin. Acta Geologica Sinica. 2010. 84(4): 518-536 (in Chinese)

Zhao Z J, Li Y P, Wu X N, et al. Conditions for migration and accumulation of Ordovician giant lithologic oil and gas reservoirs in the Tazhong region and exploration potential. China Petroleum Exploration. 2004. 9(5): 12-20 (in Chinese)

Zhou X Y, Wang Z M, Yang H J, et al. Large-scale Tazhong Ordovician reef-flat oil-gas fields in the Tarim Basin of China. Acta Geologica Sinica. 2009. 83(1): 179-188

(Edited by Hao Jie) 